\title{
Web GIS based Information System for Rural Development
}

\author{
Simhachalam Alajangi ${ }^{1}$, Kesava Rao Pyla ${ }^{2}$, Amminedu Eadara ${ }^{3}$, Prasad N S R ${ }^{4}$ \\ ${ }^{1}$ National Institute of Rural Development \& Panchayati Raj, North Eastern Regional Centre, Guwahati - 781022, India \\ ${ }^{2}$ National Institute of Rural Development \& Panchayati Raj, Rajendranagar, Hyderabad-500030, India \\ ${ }^{3}$ Departmentof Geoengineering, College of Engineering, Andhra University, Visakhapatnam-5300003, India
}

${ }^{4}$ National Institute of Rural Development \& Panchayati Raj, North Eastern Regional Centre, Guwahati - 781022, India

\begin{abstract}
Web based GIS are evolved from different Web maps and client server architecture to distributed ones. As such, Internet reshapes all functions of information systems including: gathering, storing, retrieving, analyzing, and visualizing data. Moreover, disseminating spatial information on the Internet improves the decision making processes. The importance of Web-based GIS applications for government and analyze the information they produce to establish their impact on efficiency, effectiveness and transparency of government organizations. The potential and capability of remote sensing and GIS for providing cost and time-effective resource database to prepare Resource database using remote sensing and GIS techniques to strengthen various aspects of decentralized block level planning through a coordinated approach. An attempt was made to develop a Web enabled geo-information system for the Moinabad Mandal, Ranga Reddy District, Telangana. Further this database was used to develop a web GIS based geodatabase using ArcGIS Server. It enables the users to know the information and take better decisions, better planning and monitoring in rural development sector.
\end{abstract}

Keywords: Web GIS, Geo Database, Thematic Layers, Rural Development, ArcGIS Server

\section{Introduction}

The geographic information system has been an effective tool for implementation and monitoring of ruraland urban resources. The use of GIS has been in vogue primarily due to the advantage mentioned below

- Planning of project

- Make better decisions

- Visual analysis

- Improve organizational integration

WebGIS is a new technology used for data display and to access analysis and query functionality from a GIS Server over the internet or intranet. Interactivity, user-friendliness and platform independent operation are some of the major advantages of webGIS.

\subsection{Planning of Project}

Advantage of GIS is often found in detailed planning of project having a large spatial component, where analysis of the problem is a pre requisite at the start of the project. Thematic maps generation is possible on one or more than one base maps, example: the generation of a land use map on the basis of a soil composition, vegetation and topography. The unique combination of certain features facilitates the creation of such thematic maps. With the various modules within GIS it is possible to calculate surface, length, width and distance.

\subsection{Making decisions}

The adage "better information leads to better decisions" is as true for GIS as it is for other information systems. A GIS, however, is not an automated decision making system but a tool to query, analyze, and map data in support of the decision making process. GIS technology has been used to assist in tasks such as presenting information at planning inquiries, helping resolve territorial disputes, and siting pylons in such a way as to minimize visual intrusion.

\subsection{Improving Organizational Integration}

Many organizations that have implemented a GIS have found that one of its main benefits is improved management of their own organization and resources. Because GIS has the ability to link data sets together by geography, it facilitates interdepartmental information sharing and communication. By creating a shared database one department can benefit from the work of another-data can be collected once and used many times.

\section{Web based GIS Applications}

Web application is an application that is accessed over a network such as the internet or an intranet (Shklar and Rosen, 2009). Web applications are popular because of the ubiquity of web browsers and the convenience of using a web browser as a client, sometimes called a thin client (Peng and Tsou, 2003). A key reason for their popularity is the ability to update and maintain web applications without distributing and installing software on potentially thousands of client computers and is the inherent support for crossplatform compatibility (Fowler and Stanwick, 2004).

2.1The number of web-based applications that use techniques derived from geographic information system (GIS) have seen an enormous increase (Haklay et al., 2008). Through a web interface, GIS equipped tools can provide a 


\section{International Journal of Science and Research (IJSR) \\ ISSN (Online): 2319-7064 \\ Index Copernicus Value (2013): 6.14 | Impact Factor (2015): 6.391}

wide range of planning activities. At the same time, they are able to assist the coordination between the planning authorities and public. In the planning processes, these tools, hence, can be a simple map to front-ending complex spatial analysis ranging from day-to-day to future planning which make more effective processes.

To give users' expected results of real time GIS analysis, the proper tool requirements are important with the choice of mapping, database, and development technologies and standards. This further presents an assessment involving different technologies and their value in order to achieve in a range of circumstances (Grunwald et al., 2003). Web-based GIS is a GIS distributed across a computer network to integrate, disseminate, and communicate geographic information on the World Wide Web (WWW) (Peng and Tsou, 2003). Also it provides end-users a cost-saving solution to access up-to-date spatial datasets and information comparing to other GIS systems (Horanont et al., 2002; Painho et al., 2001). Hence, an important part of every webbased GIS application is its mapping or visualization technology, which makes it possible to show data in the form of maps.

\section{Study Area}

Moinabad Mandal, Rangareddy District, Telnagana/was taken as a project covering 27 villages. The present study area is spread over between $78^{\circ} 11^{\prime} 26^{\prime \prime} \mathrm{E}-78^{\circ} 20^{\prime} 50^{\prime \prime} \mathrm{E}$ Longitude and $17^{\circ} 14^{\prime} 36^{\prime} \mathrm{N}-17^{\circ} 24^{\prime} 34^{\prime \prime} \mathrm{N}$ Latitude occupying $206 \mathrm{Sq}$. $\mathrm{Km}$ area.The Moinabad Mandal is surrounded by Rajendra Nagar, Shankarpalli, Chevella, Shabad and Shamshabad Mandals.

\subsection{Transport and Communication}

The study area Moinabad Mandal is well connected by road network. The National High-ways passing through the District and other major roads maintained by different agencies. Under Blacktop road $124.5 \mathrm{Kms}$, Cart track roads $21.5 \mathrm{Kms}$, and Footpath $5 \mathrm{Kms}$. account for $151 \mathrm{Kms}$. of total road length.

\subsection{Climate}

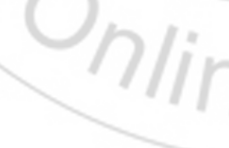

The Climate of the Mandal is characterized by a hot summer and is generally dry except during the South west monsoon season. The year may be divided into four seasons. March to May is the summer season, June to September constitutes the South West monsoon season, October to December from the North East monsoon season and January to February is the winter season.

\subsection{Temperature}

From about mid-February, both the day and night temperatures begin to increase steadily. May is the hottest month with the mean daily maximum temperature at $39.6^{\circ} \mathrm{C}$ with the onset of the southwest monsoon into the district early in June, there is an appreciable drop in temperatures and weather becomes more pleasant. In the beginning of November, the decrease in both day and night temperature is rapid. December is the coldest month with the mean daily maximum temperature at $28.6^{\circ} \mathrm{C}$ and mean daily minimum temperature at $13.6^{\circ} \mathrm{C}$.

\subsection{Rainfall}

The district has a normal rainfall of $781.0 \mathrm{~mm}$. The bulk of it is received through the South West monsoon during the period from June to September. The detailed analysis of precipitation is very important in the assessment, management and development of Land and water resources.

\section{Review of Literature}

The existing literature on Application of GIS in Planning Rural Development and Web enabled GIS information systems in different places are reviewed as fallows.

Dr. K. M. Lakshmana Rao, Head, Centre for Transportation Engineering, IPGSR, Jawaharlal Nehru Technological University, (2003) have been discussed about Rural Infrastructure Planning with emphasis on road network connectivity by Coplanar Concurrent Theory. Rural roads are an important sector in rural development, which deals in all aspects of development including agriculture, health, education, forestry, fisheries, small-scale industries, trade, commerce etc. that depends on good communication. Rural transportation network will give shape to the living environment of villagers; rather roads of rural transportation are the connectivity elements in our society. Appropriate combination of various links both technically and economically can generate rural traffic infrastructure, which should be prepared for the measure of land development.

\subsection{Bhuvan: Web Geoportal for Indian Earth Observation Data}

Bhuvan is an initiative to showcase Indian imaging capabilities with focus on Indian region, including global coverage. It is an ambitious project of ISRO to take Indian images to other value added services in multiple spatial resolutions to the people through a web geoportal for easy access to information on basic natural resources in the geospatial domain.

\section{2 e-MANCHITRA- Dr.L.R.Yadav}

The project aims at eliminating the inter-regional disparities that persist as a problem in the decentralization process, by generating village, block, district, divisional and state level thematic atlases based on SPIDER indicators. Which gives greater responsibility and power to the local bodies for effective implementation and monitoring of development programmes. This helps in reducing the time lag, increases the consistency and accuracy of data, cost efficiency and transparency, thus facilitating the superimposition of different layers on the same administrative unit.

\subsection{Kurukshetra VIS}

In the Village Information System, information is available in which Sub Division, Tehsil, Sub-Tehsil, Kanungo Circle, Patwar Circle, Block, Gram Panchayat, Parliamentary and Assembly Constituency the village falls. One can have the 


\section{International Journal of Science and Research (IJSR) \\ ISSN (Online): 2319-7064}

Index Copernicus Value (2013): 6.14 | Impact Factor (2015): 6.391

information about the Veterinary Hospital, Health Sub Centre, PHC/CHC, Hospital, Schools, ElectricitySDO/Sub Centre/Complaint Centre, Panchayat Ghar, Anganwari Centres, Talab, Stadium andChaupals. The other information available is the statistical data about the Total Area,Cultivable and Non-Cultivable Area, Population (male and females), Voters, Pensioners listand Cattles etc. The list of the development works under taken by the Panchayat departmentunder various schemes such as Indira Gandhi Awas Yojna, Chief Minister BPL Awas Yojna,IAY Scheme, TSC, MNERGA and Public Health Department is available on the system.

4.4RWASH sector web \& GIS based Management Information System, was discussed by Rob Nieuwenhuis how this system will useful for taking decisions in Nepals Rural Water Supply, Sanitation and Hygiene. Information can be retrieved as maps or reports, at any selected geographical level (from ward or scheme level up to national level). Tables can be generated using filters and sorting tools in the DSS section. Maps, reports, and tables can be printed or exported.

4.5GIS Based Modeling for Rural Infrastructure Planning have been altercated by Dr. S. K. Ghosh, Associate Professor of Civil Engineering, Indian Institute of Technology (2004) funded by Department of Science \& Technology New Delhi, a strategic GIS based model for rural infrastructure planning has been developed. Laksar block of Haridwar district in Uttaranchal has been selected for developing the prototype model.

4.6A web-based application for real-time GIS: by O. Ozdilek, a, *, D. Z. Seker, ITU, Civil Engineering Faculty, Maslak Istanbul, Turkey. As weather is the statement of the physical conditions at an instant, forecasting is of concern to one and all living bodies over the earth. As such, time immemorial weather forecasting is a subject of great concern for the physical scientists (Saseendran, 2003).

\subsection{Web-based GIS and spatial decision support system watershed management:}

Jin-Yong Choi, Bernard A. Engel and Richard L. Farnsworth. This paper explores relationships between information technology and hydrologic/water quality analysis DSS. It also describes a conceptual web-based SDSS framework in terms of system components. Further, a web-based watershed management SDSS that has been operating based on this framework using web-GIS for watershed delineation, map interfaces and data preparation, a hydrologic model for hydrologic/water quality impact analysis and web interface programs foroperation through the Internet.

\section{Methods/Approach}

\subsection{Data Used and System Design}

Toposheets:56K3NE， 56K7/NW， 56K3SE， 56K7SW, $56 \mathrm{~K} 4 \mathrm{NE}, 56 \mathrm{~K} 8 \mathrm{NW}$

Satellite data: Quick bird Image (Bing Map), IRS P6 LISS IV and PAN data
Ancillary Data and Field Data.

The following methodology has been adopted to generate the multi-layer geo database.

\subsection{Maps Preparation}

Different thematic maps namely base map, land use/land cover, cadastral maps, slope, aspect, geology, geomorphology, hydro-geomorphology, ground water potential and soils were prepared based on the standard methodology defined by National Remote Sensing Agency, Dept. of Space, Govt. of India as per IMSD guidelines.

\subsection{Base Map}

The Base map was prepared from Survey of India toposheets on 1:25,000 scale comprising drainage system, settlements, village administrative boundaries and road network for the study area. The toposheets used in the study area are $56 \mathrm{~K} 3 \mathrm{NE}, 56 \mathrm{~K} 3 \mathrm{SE}, 56 \mathrm{~K} 4 \mathrm{NE}, 56 \mathrm{~K} 7 \mathrm{NW}, 56 \mathrm{~K} 7 \mathrm{SW}$ and $56 \mathrm{~K} 8 \mathrm{NW}$.

\subsection{Existing Infrastructure Facilities Mapping}

Urban areas already got in better roads, health, educational, drinking water, sanitary, communication and other facilities compared to the rural areas. The uneven distribution of these facilities make many problems in planning. Hence the present study tries to identify the present location of the service areas and un served areas, so that suitable new location can be suggested for a balanced development in the community development block.

\subsection{Transport Facilities}

As major area of Moinabad Mandal was moderately well in population, most of them are having BT Road, Cart-Track and Footpath

\subsection{Education facilities}

As a rural area, the Moinabad Mandal has having temperate educational facilities, but for this area it is good to have this much location of educational facilities such as primary schools, secondary schools and middle schools. Moinabad Mandal has 32 primary schools, 5 upper primary schools and 14 ZP High schools. There is only one Government College in Moinabad Mandal.

\subsection{Medical facilities}

Medical facilities in Moinabad Mandal are reasonable, as it is a rural area. Moinabad Mandal has only 1 Primary Health Center, 10 Primary Health Sub Centers, 3 Allopathic Center, 1 Ayurvedic Center, 1 Unani Center, 1 Homeopathic Center, 2 Health Center and 1 Nursing Home.

\subsection{Post offices}

Moinabad Mandal also contains other facilities such as post offices. It has 11 post Offices, 1 Telegram office. All the facilities are mapped with Handheld Trimble Juno SB GPS. 


\section{International Journal of Science and Research (IJSR) \\ ISSN (Online): 2319-7064}

Index Copernicus Value (2013): 6.14 | Impact Factor (2015): 6.391

\subsection{Drainage network map}

A drainage basin is a natural unit draining run-off water to a common point. The drainage map consists of all water bodies, rivers, tributaries, perennial \& ephemeral streams, reservoirs, tanks, ponds and the entire drainage network from first order originating in the area to the last order joining the rivers, tributaries and tanks based on topography. Drainage network helps in delineation of watersheds. Drainage density and type of drainage gives information related to runoff, infiltration relief and permeability.

The drainage map is prepared using projected toposheets of Survey of India in 1:25,000 scale and updated using latest satellite data wherever deviations and new developments are observed. Based on the post monsoon satellite image extent of water spread and dry parts are updated. The water bodies which did not exist at the time of survey of toposheets, if any are also captured based on satellite imagery.

\subsection{Generation of TIN (Triangulated Irregular Network) \& DEM (Digital Elevation Model)}

For the generation of the TIN, contour data in the vector format was used to generate TIN using ArcMap 3D analyst functions. Later this TIN is converted to DEM (Elevation raster) raster form by using spatial analyst functions. Surface analysis process involves creation of elevation surfaces such as Digital Elevation Model (DEM) from elevation data available either in the form of spot heights or contours.

\subsection{Slope and Aspect Map}

The slope information is useful in understanding the topography soil types their erodability, surface drainage. Slope and relief also plays an important role in designing

i. Tone/Colour, ii) Textureiii) Patterniv) Shapev) Sizevi) Shadowsvii) Site vii) Association Terrain Elements

In addition to the image elements described above, the terrain elements listed below are also highly useful for image interpretation. They are (i) Drainage patterns (ii) Drainage texture (iii) Topography/ landform (iv)Erosion status.

The land use/ land cover categories of the Mandal have been grouped into Six Level-I classes Viz., built-up area, agricultural lands, forest lands, wastelands, water bodies and others .These Level-I classes have been further sub-divided into 11 Level-II classes. A detailed description of each of the land use / land cover class is described in the following sub sections.

Built-up landcover an area of 606.59 hectares, Crop land in the Moinabad Mandal is 6982.96 ha and double crop area is 7051.8 ha., Fallow land covers an area of 654.16 ha., the plantations covers an area of 464.76 ha, Land With/ Without Scrub area under this category is 4152 ha.,Stony waste area covers 238.3 ha. and

Water bodies cover an estimated area of 133 ha. various check dams, canal alignments and transportation planning. Slope is a vital for land capability assessment, formulation and water conservation measure.

The maximum slope was observed in the study area is below $5 \%$.

\section{Aspect}

Aspect is the direction of slope with respect to north. In output slope raster generation, aspect identifies the downslope direction from each cell to neighboring cells.

\subsection{Land Use / Land Cover Map}

Land use is a primary indicator of the extent and degree to which man has made an impression on the earth's landscape. In one sense, it is an account of impact that man has made on the ecology, the growth and relevance of the ancient civilization. Wherever agricultural resource management is positive in consonance with the contemporary and future needs of mankind, civilization has flourished. In the pastoral age, land use was developed and modified over centuries when man tried to create a particular environment suited to his requirement.

\section{Visual Interpretation}

Image interpretation processes is an act of examining images / photographs for the purpose of identifying objects and judging their significance. A systematic study of satellite images usually involves two basic visuals i.e. Image elements and Terrain elements.

Following are the eight characteristic Image elements that aid in image interpretation.

\subsection{Geology}

The most of the study area are covered with Deccan traps and some portion covered with granitic gneisses. The GSI (Geological Survey of India) geological map on 2,50,000 was used as base and updated with latest satellite imagery for the preparation of Geology map.

\subsection{Structural map}

The weak zones such as faults, thrusts, shere zones, fractures etc., and linear intrusions such as dykes, quartz viens, etc., form the structure controlled units. Irrespective of rock type and land form, they act as conduits and barriers for ground water movement. The structural map of Moinabad mandal shows the only lineaments.

\subsection{Geomorphology}

Geomorphology is the study of forms and process of landforms, which are the products of various exogenetic and endogenetic forces. The synoptic view of satellite imagery facilitates better appreciation of Geomorphology and helps in mapping of different landforms and their assemblage. The photo-interpretation criteria, such as tone, texture, shape, size, location, association, physiography, genesis of the landforms, nature of rocks/sediments, associated geological 


\section{International Journal of Science and Research (IJSR) \\ ISSN (Online): 2319-7064 \\ Index Copernicus Value (2013): 6.14 | Impact Factor (2015): 6.391}

structures, etc are to be used for identification of different landforms/geomorphic units. Lithology, drainage and contour maps are considered while preparing the geomorphology map.

For the present study area IRS P6 LISS-IV July 2010 satellite imagery and SOI Toposheets 1:25,000 scales have been used to map various geomorphic features in order to delineate groundwater potential zones in the area. Based on the interpretation of the satellite imagery and SOI Toposheets the following hydro-geomorphic units have been delineated on 1:25,000 scale.

The geomorphic units occurred in the study area are described Moderately Dissected plateau (MDP) unit is mostly seen in the central part of area covering 1229 ha. and the groundwater prospects in this unit are poor to moderate. Moderately thick lateritic plateau (MLP) mapping unit occupies an area of 341 ha of the total study area.
Structural valley (SV) unit is mostly seen along the major streams in the study area covering an area about $382 \mathrm{ha}$.

\subsection{Ground water prospects map}

Groundwater is the only reliable source for irrigation in the study area. The area experience recurrent drought conditions and acute shortage of even for drinking purpose. Shallow dug wells, which tap weathered zone, with transmissivity, but they are limited in number. The groundwater prospects in the moderately dissected plateau in the study area are poor to moderate.

Ground water prospects based on the integration of the thematic layers name the, lithology, geological structures, geomorphic units and ground water recharge conditions final ground water prospects map has been prepared indicating the ground water potential zones in the study area.

Table 1: Ground water prospects

\begin{tabular}{|c|c|c|c|c|c|}
\hline $\begin{array}{c}\text { Mapping } \\
\text { Symbol }\end{array}$ & $\begin{array}{c}\text { Hydro geomorphic } \\
\text { Units }\end{array}$ & $\begin{array}{c}\text { Litho- } \\
\text { Stratigraphy }\end{array}$ & Structure & Description & Ground water prospects \\
\hline SV & Structural valley & Basalts & $\begin{array}{c}\text { Associated } \\
\text { with Fractures/ } \\
\text { Lineaments }\end{array}$ & $\begin{array}{c}\text { The valley portions of } \\
\text { basalts weathered to a } \\
\text { considerable depth and } \\
\text { associated with fractures } \\
\text { /lineaments. }\end{array}$ & $\begin{array}{c}\text { Moderate to good. Good yields are } \\
\text { expected along } \\
\text { Fractures/Lineaments. }\end{array}$ \\
\hline MDP & $\begin{array}{c}\text { Moderately } \\
\text { dissected plateau }\end{array}$ & Basalts & -do- & $\begin{array}{c}\text { Shallow valleys/Gullies } \\
\text { with gentle sloping land } \\
\text { developed due to stream } \\
\text { erosion on plateau. }\end{array}$ & Poor to moderate. \\
\hline MLP & $\begin{array}{c}\text { Moderately thick } \\
\text { lateritic plateau }\end{array}$ & $\begin{array}{c}\text { Laterites as capping } \\
\text { over basalts }\end{array}$ & - do- & $\begin{array}{c}\text { Elevated flat land with } \\
\text { moderately thick } \\
\text { lateritic } \\
\text { Plateau. }\end{array}$ & $\begin{array}{c}\text { Moderate. Ground water occurs } \\
\text { mainly in the weathered and } \\
\text { fractured zones of basalts. }\end{array}$ \\
\hline
\end{tabular}

In this present study area covers the 382 ha in moderate to good, 341 ha in moderate and 1231 ha in poor to moderate unit occupies an area of the study area.

\subsection{Soil}

Soil is a major component of land system which provides a medium for plant growth. The potentials and limitations of a soil for sustained use under agriculture, horticulture, silvipasture and forestry as well as its response to irrigation and other management practices are controlled by its inherent qualities and characteristics. The quality of the soil is a function of its morphological, morphometric, physical and chemical characteristics. These characteristics are expressed a taxonomic class as depicted on soil map with locational reference. Soil mapping of the region is intended to serve as a crucial input for preparing an integrated plan for sustainable development of the area. Soil surveys provide desired information on nature, location, extent and physio-chemical characteristics along with their spatial distribution.

The specific objectives of the soil mapping are Identification, characterization and classification of the soils of the area, Generation of derivative maps and Land evaluation for food/cash and horticultural crops.
Soil map is showing distribution of soil types and/or soil properties (soil $\mathrm{pH}$, textures, organic matter, depths of horizons etc.) in the area of interest. It is typically the end result of a soil survey inventory, i.e. soil survey. Soil maps are most commonly used for land evaluation, spatial planning, agricultural extension, environmental protection and similar projects. Traditional soil maps typically show only general distribution of soils, accompanied by the soil survey report. Many new soil maps are derived using digital soil mapping techniques. Such maps are typically richer in context and show higher spatial detail than the traditional soil maps. Soil maps produced using (geo) statistical techniques also include an estimate of the model uncertainty. In the study area, Red Loamy soils predominate with coverage of $67 \%$ of the villages of the Mandal. The Soils are poor textured and easily drained. Sandy loamy soils come next with $33 \%$ of the villages of the Mandal.

\subsection{Land Capability Classification}

The knowledge of land capability classification is prerequisite and important for planning, implementation \& execution of the work of soil and water conservation programmes. Land capability classification is a systematic classification of different kinds of land according to those properties which determine the ability of the land to produce 


\section{International Journal of Science and Research (IJSR) \\ ISSN (Online): 2319-7064}

Index Copernicus Value (2013): 6.14 | Impact Factor (2015): 6.391

common cultivated crops \& pasture plants virtually on permanent basis (Tejwani, 1976). This classification is made primarily for agricultural purposes and it enables the farmer to use the land according to its capability and to treat it according to its need. The concept of land capability classification has been developed in USA for soil conservation on farmlands.

\subsubsection{Land Capability Classification Scheme}

The land is divided into eight capability classes, which are numbered in Roman numerals from I to VIII. Each class assigned a standard color. These eight classes are grouped in two Land use suitability groups viz., (i) "Land suited for cultivation and other uses" (class I to Class IV), and (ii) "Land not suited for cultivation, but suitable for other uses" (Class V to Class VIII). The land capability classes are based on the degree of erosion hazards and the intensity of limitations for use. Class I land is the best and the most easily farmed land and has no hazard or limitation for use, while in class VIII land nothing of economic value can be produced, and it may need protection \& management to conserve other more valuable lands and watersheds.

\subsubsection{Land capability Subclasses}

Land capability subclasses represent the dominant limitation for agricultural use. Class I soils do not have limitations for crop production and are not assigned a subclass.

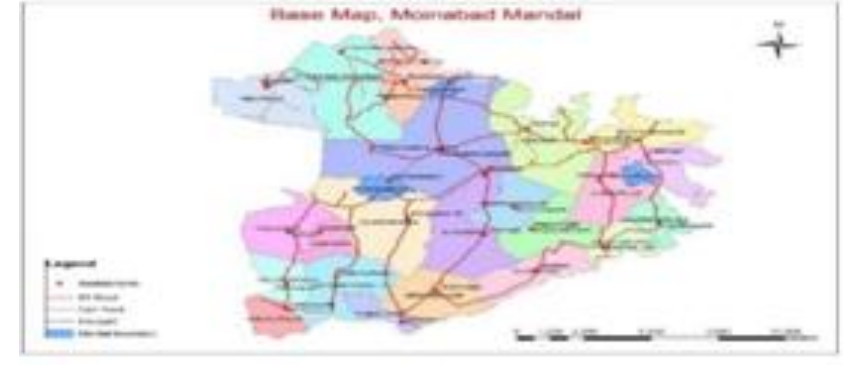

Figure 1: Base and Educational Facilities Map

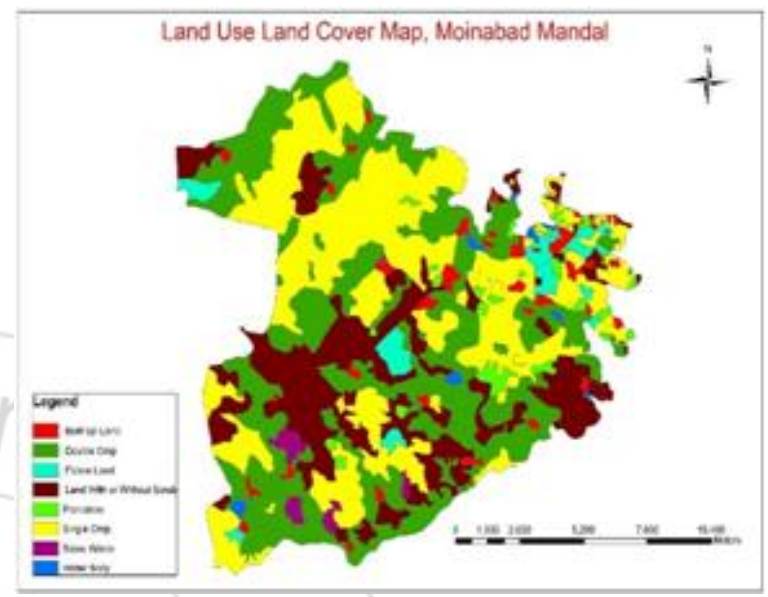

Figure 2: Land Use / Land Cover Map

\subsection{Land Irrigability Classification}

The classification is based on effective soil depth, soil texture, soil permeability, coarse fragments etc. The soils are grouped into soil irritability classes according to their limitations for sustained use under irrigation, regardless of their location or the size of the individual mapping unit.

\subsubsection{Land Irrigability classes}

The suitability of land for irrigation depends on physical, economic and cultural factors in addition to soil irrigability classes. Besides, the following physical and socio-economic factors are considered in determining land irrigability classes.

- Quality and quantity of irrigation water available from surface and ground water resources.

- Requirement of drainage.

- Cost of production of crops and their yield potentials.

- Costs of land development.

- Factors effecting input-output ratio.

Based on the integration of the different thematic Layers in the GIS Domain the following Soil and water conservation measures were suggested based on the soil, slope, Drainage pattern and the present land use pattern for the study area.

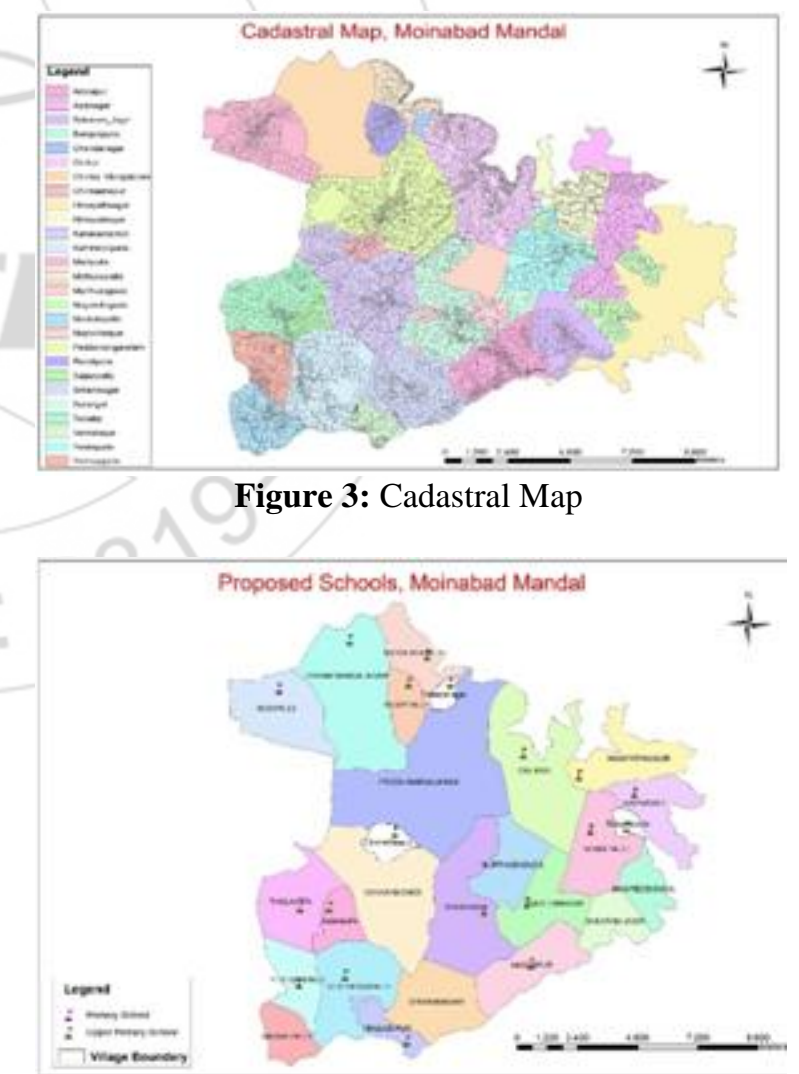

Figure 4: Proposed Schools Map 


\section{International Journal of Science and Research (IJSR) \\ ISSN (Online): 2319-7064}

Index Copernicus Value (2013): 6.14 | Impact Factor (2015): 6.391

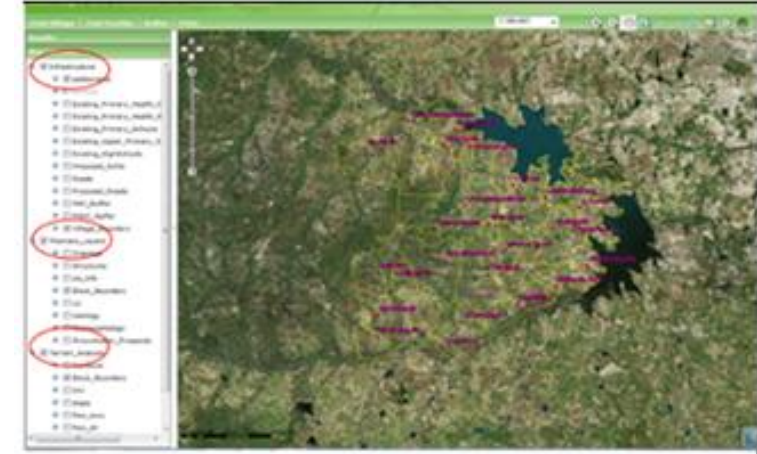

Figure 5: Main interface of Web Application

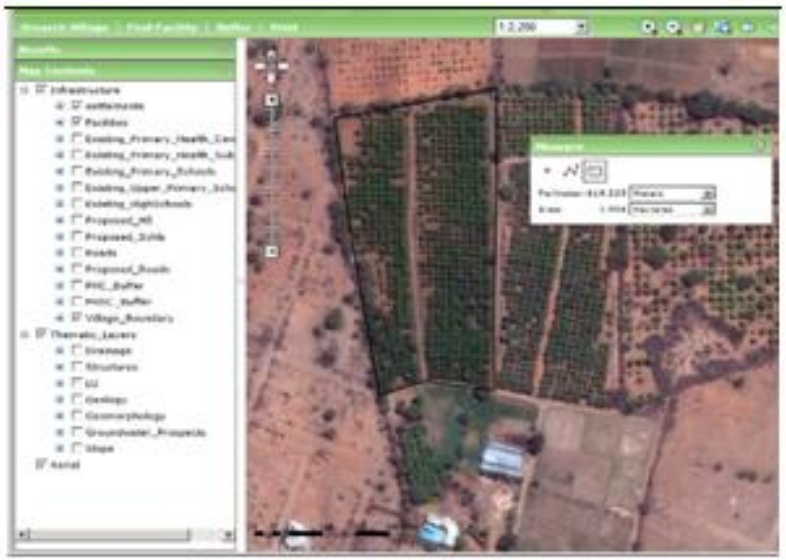

Figure 6: Calculating area in Web Application

\section{References}

[1] Lakshmana Rao, M., (2003) Rural Infrastructure Planning with emphasis on road network connectivity by Coplanar Concurrent Theory, Map India.

[2] Chris Bazlington, (2002) Geographical Information Systems and Housing Needs.

[3] Ghosh, S. K., (2004), GIS Based Modeling for Rural Infrastructure Planning.

[4] Groundwater Prospects Mapping using Remote sensing and GIS (Manual) by NRSA, 2008.

[5] Jin-Yong Choi, Bernard A. Engel and Richard L. Farnsworth, Web-based GIS and spatial decision support system watershed management, 2012.

[6] Ratan Tata Trust and the National Council of Applied Economic Research (NCAER), New Delhi (2003), the India Rural Infrastructure Report.

[7] Jeanne H. Armstrong, Meir Gross, John R. Mullin and Robert D. Yaro (2006), Infrastructures Planning in Rural Massachusetts.

[8] The Need for a Spatial Data Infrastructure, geospatial today (May 2002), vol 1 Issue 1.

[9] "ArcGISServer,://webhelp.esri.com/arcgisserver/9.2/dot net/manager/concepts/whats_server.htm.

\section{Conclusion}

The present study emphasizes the power of web GIS technology which will help the decision makers at block level to better understand and evaluate spatial data by creating graphic displays using information stored in the database. Also, this study identified the existing resources which can be used for planning of RD programmes like MGNREGS, PMGSY, NRLM, NRHM, SSA etc. The geovisualization also gives the gap of facilities within the geographical region and this study also proposed the required facilities for rural development.

\section{Future Scope}

A GIS based information system will help the government in planning, implementation and monitoring of various rural development projects for development in different fields at much faster rate which in turn will make the state technologically more developed.

This analysis has confirmed the need for spatial planning, which can achieve the desired results of economic, social interaction and overall development of a region. This study involves a methodology for rank ordering the various settlements, so that, priorities for linking the settlements can be worked out.

This GIS database will be customized to meet the requirements of stake holder departments/concerned in providing the digital resource databases and any other requirements of the block, based on their problems/ priority/ developmental programmes at Village/ Block level. 